\title{
11. Equality as a Basic Human Right: Choice and Responsibility
}

\author{
Archana Parashar
}

Drawing on post-structural theory, this chapter argues for a reconceptualisation of the role of the judge in equality jurisprudence. It suggests a closer link between choice and responsibility, which would require revising conventional theories of judicial reasoning. The approach would allow the illusory distance between the decision maker and the decision to be bridged. The chapter concludes by drawing attention to the transformative potential of legal education for training law students as independent and ethical thinkers who firmly grasp the relationship between choice and responsibility.

\section{Introduction}

The recent senate review of the Sex Discrimination Act 1984 (Cth) (SDA) became the occasion for asking whether the legislation is adequate for the task of eliminating discrimination and promoting gender equality. ${ }^{1}$ The Senate, however, did not ask the initial question of how the aims of the SDA might be ascertained and how we would measure its effectiveness. These are recurring questions in legal scholarship and as yet remain unresolved. In this chapter, instead of focusing on measuring the effectiveness in quantitative terms, I propose to focus on the normative effect and the aim of anti-discrimination legislation.

There is robust discussion in legal scholarship about whether law can be a means of intentional and progressive social change. A related stream of thought questions whether legislation is required or effective for achieving social change and suggests instead that education is a better tool of social transformation. I take these as non-issues for this chapter because, everything else notwithstanding, the normative effect of legislation is undeniable. Therefore, as a starting point, I wish to address the narrower issue of what kind of equality legislation the

\footnotetext{
1 Standing Committee on Legal and Constitutional Affairs, Report on the Effectiveness of the Commonwealth Sex Discrimination Act 1984 in Eliminating Discrimination and Promoting Gender Equality, Parliament of Australia, Canberra, 2008, <http://www.aph.gov.au/Senate/committee/legcon_ctte/sex_discrim/report/ index.htm>
} 
law should aim for. In the senate committee review of the $S D A$, this issue was framed in part as whether we need an Equality Act. ${ }^{2}$ There were arguments on both sides and the recommendation was for a further, wider inquiry. The following argument is my effort to identify some of the issues that must be a part of the debate about the design and scope of an Equality Act.

The initial question of what concept of equality should be pursued in legislation is answered in part by asking why equality is desired. It is uncontroversial that the demand of equality is a manifestation of the desire for non-discrimination/ fairness/dignity of every human being. Legislation that will capture these aspirations best will not be in limited-scope legislation such as the current $S D A$. An Equality Act can serve as the shorthand way of describing the human rights aim of the legislation. That said, the real legislative formula remains to be developed. Moreover, there is always a large gap between the aims and their realisation and it is reasonable to expect that the Equality Act would be no different in this regard.

Therefore, it is necessary to address two separate issues: the design of the legislative provisions and the interpretation and application of these provisions. In brief, I wish to argue that it is important to formulate the legislative provisions as clearly and succinctly as possible, but however perfect the legislative formulations are, they will nevertheless be interpreted by the judiciary. Therefore, focusing merely on designing better legislative provisions is an insufficient remedy for the identified shortcomings of the law. Instead, it is essential that we also address the jurisprudential theories of how the courts can and should interpret these provisions. Therefore the two tasks - that is, design of the legislation and re-conceptualisation of the judicial role-require simultaneous attention.

My main aim in this chapter is to analyse the shortcomings of the extant literature on the nature of judicial role and argue for the re-conceptualisation of the task of judicial interpretation. In part, this re-conceptualisation of the judicial role is supported by the post-structural theories of the constructed nature of all knowledge, but I wish to extend these insights. I wish to argue that the links between judicial choice and responsibility should be the central focus of the jurisprudence of equality.

I begin with a brief discussion of the desirable design of an Equality Act. I argue that equality should be conceptualised as a basic human right. This is, however, merely to set the context for the subsequent argument about the judicial role. This is followed by an analysis of the debates about the appropriate role of the judiciary in implementing legislation. I argue that the conventional

2 I will not analyse the merits of the submissions made or the eventual recommendations because my main aim in this chapter is to move beyond the issue of designing appropriate legislative provisions. 
theories about the nature of judicial reasoning need to be revised in order to pin the responsibility on the individual judge for choosing an appropriate interpretation. This is necessary to bridge the illusory distance between the decision maker and the decision and for the anti-discrimination legislation to fulfil the promise of achieving substantial equality. To achieve such change in the conventions of theorising, it is necessary that legal education develops the critical and self-reflective capacities of thinkers.

\section{Legislative Definition of Equality}

An extensive philosophical literature on the concept of equality already exists but this is not the focus of my chapter. ${ }^{3}$ Sex equality debates extended these original arguments about equality to women, but feminist thinkers are also the ones who have problematised the concept of equality more than any other group of thinkers. Perhaps unsurprisingly this abundance of discussion has not as yet brought a resolution to the meaning of equality that everyone can agree on. In the contemporary debates about conceptualising equality there is, however, a big difference from the early feminist efforts when the struggle was to gain acceptance for the concept of gender justice itself. ${ }^{4}$ In the contemporary context, it is widely accepted that inequalities of sex, race, age, sexuality, ability, and so on, are all illegitimate and the debates now are more about which strategies to use to eradicate them. ${ }^{5}$ For example, Squires says that what it means is that gender equality advocates are expected to pursue gender equality within a wider equalities framework with attention given to the intersection of various axes of inequalities. This concern is more accurately described as a concern with diversity. ${ }^{6}$

This shift in the conceptualisation of equality is to an extent a function of the advent of the post-structural method of analysis and thus also carries the tendency to valorize diversity. The broadening of the concept of gender equality goes hand in hand with a reluctance to rank in importance various kinds of discrimination. It is also impossible logically to argue for directed social change as no concept of justice or fairness can be justified. I believe that the relativism

3 For a comprehensive discussion, see: Wojciech Sadurski, Equality and Legitimacy, Oxford University Press, New York, 2008. See also: Amartya Sen, Inequality Re-Examined, Oxford University Press, UK, 1992.

4 For a discussion of legal debates on gender equality, see: Rosemary Hunter (ed.), Rethinking Equality Projects in Law: Feminist Challenges, Hart Publishing, Portland, Ore., 2008.

5 For a wide-ranging discussion on this topic, see: Katherine M. Franke, 'The Central Mistake of Sex Discrimination Law: The Disaggregation of Sex from Gender' (1995-96) 144 University of Pennsylvania Law Review 1.

6 Judith Squires (The New Politics of Gender Equality, Palgrave Macmillan, Basingstoke, UK, 2007, p. 16); but she also points out the danger of losing the focus on gender equality. See also: Michele Moody-Adams, ‘Reclaiming the Ideal of Equality' in Barbara S. Andrew, Jean Keller and Lisa H. Schwartzman (eds), Feminist Interventions in Ethics and Politics, Rowman and Littlefield Publishers, Oxford, 2005. 
of this way of thinking can be logical but it is not essential. ${ }^{7}$ Since all concepts of equality are equally constructed in discourse, rather than treating them all as equally relevant, the focus must be to explain why one construct is to be preferred over another and what are the consequences of such choices.

Anti-discrimination law is a manifestation of the aspiration that law should help in achieving a fair society, ${ }^{8}$ although it is one that is very regularly defeated by the judiciary. The more common and plausible response to this problematic outcome is that the legislative definition of non-discrimination or equality should be changed. This suggested course of action, however, assumes that legislative drafting can fix the problem. There are many problems in this suggestion but even if, for argument's sake, this explanation is accepted, changing the definition nevertheless requires a prior articulation of what is or should be the aim of the legislation. Without being cynical, the desire to be fair can be seen as an uncontroversial aspiration and with that starting point it is easy to argue that equality should be given a substantive rather than a formal content in the legislation. One way of proceeding is to conceptualise equality as a basic human right.

\section{The Human Rights Model for Equality}

I draw on the literature on the US Equal Rights Amendment (ERA) to argue that we require an overarching principle that discrimination is unacceptable and this can best be achieved by a constitutional guarantee of equality as a fundamental or human right. ${ }^{9}$ The main issue here is not whether such a human right should be a constitutional or legislative guarantee. Rather the debates about a constitutional equality right serve to focus attention on the scope or the extent of such a right. A merging of the concepts of non-discrimination and equality is necessary for conceptualising equality as a human right. ${ }^{10}$ Therefore we need legislation that guarantees equality, and such an equality right can

7 There is extensive discussion in the literature about directed social change in the light of post-structural analyses. For an introduction, see: Nancy Fraser, Justice Interruptus: Critical Reflections on the 'Postsocialist' Condition, Routledge, New York, 1997; Jodi Dean (ed.), Feminism and the New Democracy: Resisting the Political, Sage, London, 1997.

8 Christopher McCrudden (ed.), Anti-Discrimination Law, Dartmouth Ashgate, Aldershot, UK, 2004, pp. xixxxii. See also, for a discussion in the context of racial discrimination but with an argument that is extendable to all bases of discrimination that more than formal equality is desirable in anti-discrimination jurisprudence: Tracy E. Higgins and Laura A. Rosenbury, 'Agency, Equality and Anti-Discrimination Law' (1999-2000) 85 Cornell Law Review 1194.

9 For a comprehensive review of issues, see: Martha Davis, 'The Equal Rights Amendment: Then and Now' (2008) 17(3) Columbia Journal of Gender and Law 419.

10 This is a fairly common idea in the literature. See, for example: Ruth Colker, 'Anti-Subordination Above All: Sex, Race and Equality Protection' (1986) 61 New York University Law Review 1003. See also: Australian Law Reform Commission, Equality Before the Law: Women's Equality, Report No. 69, Australian Law Reform Commission, Sydney, 1994, Part II. 
operate as akin to a constitutional guarantee and thus broaden the scope of the right to include both state policies and individuals' actions. More importantly, it will be a blanket guarantee rather than picking and choosing which grounds of discrimination are to be proscribed-but admittedly with a drawback of reduced visibility for gender as a separate ground. ${ }^{11}$

Some of the objections to the ERA are a good indicator of the importance of such a norm. The objections are particularly instructive in that they identify the areas that the opponents of the ERA do not want to be covered by the equality guarantee. For example, the opponents of the $E R A \operatorname{did}$ not wish equality to govern the organisation of the military, marriage or other issues of privacy, including abortion and homosexuality. ${ }^{12}$ As we now know, over time, greater public acceptance of the principle of non-discrimination on some of these grounds has come about. ${ }^{13}$ Discrimination on the other remaining grounds continues to persist, however, and to be justified. The point is that the rationales for discrimination on particular grounds continue to be as arbitrary as ever despite the increased acceptance of the non-discrimination principles. It is in this context that the introduction of an Equality Act has the potential to create a normative force for treating all discrimination as suspect or unjustifiable.

Australia has a protracted history of unsuccessful efforts to introduce a constitutional bill of rights and the current move to introduce one as a statutory measure is the most recent 'compromise' development. ${ }^{14}$ Given this shift in focus of the human rights movement, it might be argued that any proposed Equality Act can be part of such human rights legislation and there is no need for separate legislation. While there is an overlap between the human rights discourse and the demand for equality, there are important reasons for treating equality as a distinct issue for the time being. It is important to remember that the traditional scope of human rights has been different from the demand for equality. In human rights discourse, it is more a case of upholding equality of various identified rights described as fundamental or human rights. Treating equality itself as a human right requires a conceptual shift but it is a necessary shift if genuine non-discrimination is the legislative goal. This goal can be better

\footnotetext{
11 See also Margaret Thornton's observations in her submission to the Senate Standing Committee on Legal and Constitutional Affairs (Report on the Effectiveness of the Commonwealth Sex Discrimination Act 1984 in Eliminating Discrimination and Promoting Gender Equality, Ch. 4, para. 4.60).

12 Jane J. Mansbridge, Why We Lost the ERA, University of Chicago Press, Ill, 1986.

13 See also Barbara Sullivan ('Sex Equality and the Australian Body Politic' in S. Watson [ed.], Playing the State, Allen \& Unwin, Sydney, 1990) for an account of the enactment of the SDA and the compromises made to appease the opponents who feared, inter alia, that the Act would encourage women to give up their roles as wives and mothers.

14 Gilbert and Tobin Centre of Public Law, History of Charters of Human Rights in Australia, <http://www. gtcentre.unsw.edu.au/Resources/cohr/historyChartersofHumanRights.asp $>$. It has, however, met with stiff opposition; see Claire Chaffey, 'Human Rights Proposal Still Afloat', Lawyers Weekly, 22 February 2010, Lexis Nexis, <http://www.lawyersweekly.com.au/blogs/top_stories/archive/2010/02/22/human-rights-proposalstill-afloat.aspx $>$
} 
achieved through a stand-alone Equality Act. Therefore, the design of such equality legislation must be overarching like a constitutional guarantee but it must be embodied in separate legislation. ${ }^{15}$

In making this proposal for conceptualising equality as a basic human right, I am fully aware that human rights are not a panacea where other legal rights have well-documented shortcomings. ${ }^{16}$ Nevertheless, as argued by various minority scholars, legal rights are critiqued primarily by privileged scholars. With all their shortcomings, legal rights are still valued and pursued by the relatively more oppressed minorities in the same liberal and developed societies that produce the most trenchant critique of rights. Moreover, as argued by Lacey, rights are not transcendent or objective but are a product of contestations and they can be seen as 'an emergent critical force within modern societies' and 'as a framework within which new political ideas can be articulated'. ${ }^{17}$ The critiques of law and rights in particular operate to demonstrate the contingency of our normative concepts, including the concepts of rights, justice and equality; and by implication indicate that these concepts can be redefined in radically different ways. ${ }^{18}$

It is in keeping with the post-structural insights about construction of knowledge that legal analysis needs to focus on the specific sites of construction of meaning and, in common-law jurisdictions, this site is pre-eminently judicial interpretations of precedents and statutory provisions. Therefore, the main focus of the rest of my argument is on how such reconstruction of the concept of equality might happen.

\section{Judicial Interpretation and Responsibility}

The legal literature on assessing the anti-discrimination laws and judicial pronouncements is replete with analyses suggesting interpretations that are plausible and desirable but very often are not the ones adopted by judges. ${ }^{19}$ There is a wide gap between the ideal and the real and, despite the exhortations

\footnotetext{
15 The relative merits of constitutional versus legislative measures are an important but separate topic and one outside the scope of the present chapter.

16 Shelley Wright, 'Human Rights and Women's Rights' in K. E. Mahoney and P. Mahoney (eds), Human Rights in the Twenty-First Century, M. Nijhoff, Dordrecht, Boston, 1993. See also: Didi Herman, 'Beyond the Rights Debate' (1993) 2 Social and Legal Studies 25.

17 Nicola Lacey, 'Feminist Legal Theory and the Rights of Women' in Karen Knop (ed.), Gender and Human Rights, Academy of European Law, Oxford University Press, UK, 2004, p. 42.

18 Ibid., p. 45.

19 For an incisive critique of the decisions under the SDA, see: Margaret Thornton, 'Sex Discrimination, Courts and Corporate Power' (2008) 36 Federal Law Review 31. For an analysis of decisions under the Racial Discrimination Act, see: Jonathan Hunyor, 'Skin-Deep: Proof and Inferences of Racial Discrimination in Employment' (2003) 25 Sydney Law Review 535. See also: Beth Gaze, 'Context and Interpretation in AntiDiscrimination Laws' (2002) 26(2) Melbourne University Law Review 325.
} 
of scholars, judges mostly seem unable to do anything about it. ${ }^{20}$ While everyone else seems to be able to understand equality as symbolising fairness or nonarbitrariness, legal scholars and judges, in particular, tie themselves in knots about interpreting what would be an appropriate meaning of equality. My argument is that a genuine rethinking of legal equality requires a deconstruction of the contemporary methods of legal interpretation. What I mean by this is best illustrated with the help of the story of the SDA since its enactment. ${ }^{21}$

All liberal legal systems gain legitimacy by claiming to uphold the fundamental principle of equality. The $S D A$, as with all other anti-discrimination laws, was enacted as recognition of the inadequacy of the formal equality guarantee of liberal legal systems. That is, even though liberal legal systems are premised on the equality of all legal subjects, feminists successfully illustrated the relevance of gender differences in legal discourse and the disadvantages in law suffered by women, despite the assumption that legal standards are neutral. As a result, the $S D A$ was enacted to rectify this flaw in formal legal equality but once enacted it ended up being interpreted as a guarantee of formal equality. ${ }^{22}$ Why the judges are unable to see the absurdity of this situation is hard to explain-except by deconstructing the mechanism of judicial/legal reasoning. The importance of focusing on the concept of legal reasoning is evident furthermore in that the specialised tribunals set up under anti-discrimination laws have failed to establish new ways of interpreting the non-discrimination/equality guarantees. The specialised tribunals set up to administer anti-discrimination laws have not managed to replace the dominant methods of legal reasoning primarily because it is their place in the hierarchy of the courts that makes them ineffective especially since the higher courts do not feel the need to focus on the nature of their task. ${ }^{23}$

\footnotetext{
20 This is also evidenced by the regular reversing of lower court decisions by the Australian High Court in discrimination complaints, as discussed by Thornton in 'Sex Discrimination, Courts and Corporate Power'. 21 See, for a comprehensive analysis, Margaret Thornton, The Liberal Promise: Anti-Discrimination Legislation in Australia, Oxford University Press, Melbourne, 1990.

22 There is some difference of opinion on this issue, as in Australia the SDA as well as most other antidiscrimination laws use gender-neutral language. The courts have without fail interpreted this as a guarantee of formal equality. Many commentators on these laws as well accept that the laws were enacted to guarantee formal equality; see: Thornton, 'Sex Discrimination, Courts and Corporate Power'; Beth Gaze, 'The Sex Discrimination Act After Twenty Years: Achievements, Disillusionments and Alternatives' (2004) 27(3) UNSW Law Journal 914. I prefer the interpretation put forward by Sadurski, however, that it is up to the courts to conceptualise discrimination on the basis of the effect of any classification rather than on the fact of classification per se: Wojciech Sadurski, ‘Equality Before the Law: A Conceptual Analysis' (1986) 60 Australian Law Journal 131.

23 Institutional design is a relevant avenue for exploring possibilities of making anti-discrimination law a means of achieving substantive equality but it is outside the scope of this discussion. It is for the same reason that I am not discussing the merits of changing the regulatory regime of these laws. See Belinda Smith, 'It's About Time for a New Regulatory Approach to Equality' (2008) 36 Federal Law Review 117.
} 
There is much literature suggesting avenues of making anti-discrimination laws deliver on their promise of equality. ${ }^{24}$ As far as I have been able to ascertain, however, there is not anything written on re-conceptualising the category of judicial reasoning as one way of proceeding. It is not my intention to attribute mala fides to the judges; rather I am more inclined to ask why it is so. What is it about being a superior-court judge that prevents one from seeing the discrimination in the alleged situation? Moreover, what can be done to make the enterprise of interpretation a socially responsible one? These are the very questions usually silenced by the mainstream jurisprudential insistence on claiming that

- the judicial task is one of applying the law

- professional reasoning is different from ordinary reasoning

- institutional role responsibility is separate from personal responsibility.

These claims of conventional jurisprudence create the possibility of deflecting attention from the choice or discretion exercised by the judges in every instance of interpretation. Recognising this is an initial step towards conceptualising the judicial act of interpretation in a manner that emphasises choice and thus the agency of the judges in attributing meaning to legal rules. Once the element of choice is acknowledged, the responsibility for that choice becomes inevitable, for it follows that judges would strive for socially just outcomes if they were the ones exercising choice.

\section{Judicial Task as One of Applying the Law}

It is an article of faith in jurisprudence to conceptualise the judicial task as one of applying the law or more specifically as one of not making the law. While the mainstream jurisprudential writings give extensive reasons for a conception of judicial authority as constrained reasoning - otherwise described as legal reasoning ${ }^{25}$ - it is also true that critical theorists have demonstrated the extensive discretion that judges exercise and in doing so are inevitably influenced by an array of extra-legal factors. Moreover, the nature of language and how it operates form the core of post-structural analyses that explain how interpretation requires attributing meaning. The obvious conclusions of such analyses challenge the conventional view of legal reasoning that invokes the

\footnotetext{
24 See, for an argument that private contract law is able to yield better results than public equality laws: Belinda Smith and Joellen Riley, 'Family Friendly Work Practices and the Law' (2004) 26 Sydney Law Review 395.

25 This is one of the extensively discussed issues in conventional jurisprudence scholarship, but it is not my main concern here. I have analysed some of these issues in my chapter 'Responsibility for Legal Knowledge' in Amita Dhanda and Archana Parashar (eds), Decolonisation of Legal Knowledge, Routledge, Delhi, 2009, p. 178.
} 
separation-of-powers doctrine, the desirability of democratic control of legal policy and a particular understanding of how language operates. This critical legal literature has its own set of shortcomings but the more important issue for now is that despite such extensive critical scholarship the dominant view about the nature of the judicial task remains unchanged. Therefore it is necessary to focus on how - by using which legal concepts - the mainstream legal scholars as well as judges in particular manage to steer clear of this literature and thus help maintain the hegemony of the conventional view that legal reasoning is a special kind of reasoning.

I argue that it is the particular conception of legal reasoning, the idea that judges 'apply' the law and that there is a division of authority between the legislature and the judiciary, which enables the mainstream thinking to persist. One important consequence of this conception of legal reasoning is that it distances the decision maker from their decision because it is not 'their' decision. As a consequence, judges, when interpreting anti-discrimination laws, can dissociate themselves from the consequences of their interpretation. Moreover, if the judges fail to uphold justice or fairness as the guiding principle in their judgments, they are permitted or even encouraged to do so by the prevailing orthodoxy that they are simply applying an already existing law.

Such a conception of the judicial role is also a logical extension of the positivist understanding of law that dissociates law and morality. The legislators can but are not compelled to create a just or fair law, but if they have failed to do so the judge must remain agnostic. Thus, there is no possibility of expecting the judges to strive for just or fair results as they are 'constrained' by law and not free to pursue their own preferences. Although there is abundant evidence that there is no pre-constituted law waiting to be discovered and applied by the judges, ${ }^{26}$ the mainstream jurists object that any other conception of the judicial task will 'give' judges too much power.

There are two different issues that arise out of this insistence of the mainstream jurisprudential view of the judicial task: the claim that it is necessary to maintain the legitimacy of judicial authority and that otherwise the judges will have unlimited power. Although it is undeniable that law and judges require continued legitimacy, it can be better achieved by ensuring that judges engage in interpretations that strive to achieve justice. One way of proceeding is to focus on the fact that the judges are making choices and deploying their expertise, intelligence, good conscience and so on to make reasonable decisions and not saying so does not change the facts. Second, the gains made by artificially constraining judges are lesser than the loss of opportunity to engage the judges

26 For a classical contrast, see the difference between the arguments of Stanley Fish and Dworkin in the discussion below. 
in striving for justice and fairness in the law. If it could be openly acknowledged that judges exercise discretion in interpreting legal rules, one could then focus on how best to do so. ${ }^{27}$

It is difficult, however, to acknowledge that judges exercise discretion in every task of interpretation because it raises the question of why the judges can be entrusted with this authority. Or put differently, what is the basis of judicial authority? This is an unstated and unresolved issue of contemporary jurisprudence. $^{28}$ The earlier common-law understanding of law and the conception of the judicial task were complementary in so far as common law was seen as the expression of natural reason and the judges who were confined to applying this law were thus upholding the fair and just natural law. With the contemporary positivist understanding of law, however, the same confidence in the judge's capacity is sought to be achieved by the concept of 'constraint' that is, the judge is not free to do whatever. The judge is bound by the law. The problem of course is that the law as enacted by the Parliament is now anything at all (that has the correct pedigree). The fiction of the democratic control of Parliament does nothing to ensure that laws made are just laws. ${ }^{29}$ It is in this context that insisting on the constrained role of the judge writes out the possibility of any aspiration for justice or fairness in law.

In the meantime, judges engaged in 'applying' the law nevertheless have to choose between at least two interpretations of the same law. It thus becomes problematic to assert that judges have no more to do than 'apply' whatever the legislature enacts. Dworkin has tried valiantly to rescue the legitimacy of judicial authority by postulating that judges are constrained in exercising their discretion and therefore can be trusted to uphold the law rather than create it anew. ${ }^{30}$ The law so upheld is a combination of rules and principles and the judges are the final authority on what weight to give to any principle. The obvious problem with this conception of the judicial task is that there is no way of knowing which principles are relevant and what weight they will carry before the judge decides. In this conception of the judicial task, the judge remains the ultimate arbiter of meaning, exercising choice but this time with the dubious guarantee that the law constrains the judge.

\footnotetext{
27 As I have argued above, however, merely changing the legislative formula is not enough. I therefore differ from the argument made by Belinda Smith in this volume.

28 For a comparative study discussing the more conventional issues, see: Maur Cappelletti, 'Who Watches the Watchmen? A Comparative Study of Judicial Responsibility' (1983) 31 American Journal of Comparative Law 1. For an interesting discussion, see: Michel Rosenfeld, 'Deconstruction and Legal Interpretation: Conflict, Indeterminacy and the Temptations of the New Legal Formalism' in Drucilla Cornell, Michel Rosenfeld and David Gray Carlson (eds), Deconstruction and the Possibility of Justice, Routledge, New York, 1992, p. 152.

29 Even though a theoretical possibility exists of legislatures creating perfect laws, it does not detract from the following argument.

30 Ronald Dworkin, Law's Empire, Harvard University Press, Cambridge, Mass., 1986.
} 
I do not know of any satisfactory resolution of this problem as the critical theorists' answers are equally even if differently problematic, as analysed below.

\section{Critical Theorists and the Basis of Judicial Authority}

With slight variations, all post-structural critiques point out that knowledge is constituted and in turn constitutes reality. That being the case, how law is constituted becomes the initial question for such theories. Even though these analyses are of law in general, their primary focus invariably is on the judicial pronouncements. Moreover, all of these theorists seem to be mesmerised by the desire to disprove the claims of law as being about fairness, equity or its objective and principled nature. As examples of this kind of analysis, one has only to point to the extant literature that explicates the power of law as the 'force of law' or the 'racism of law', and so on. ${ }^{31}$ It is not in doubt that such analyses are a necessary challenge to the mainstream view of the law as being about fairness or justice, but neither is it enough to stop here. Any analyses that show how law is the very means of oppression and discrimination but stop there are deterministic. They do not leave any avenue to explore whether law could also be the means of achieving non-discrimination.

At the very least, this kind of analysis makes the status quo look inevitable. The effect of this kind of theorising is as exclusionary and debilitating as that of the mainstream theorising it was meant to critique. Surely post-structural scholars must accept responsibility for their analyses - that all meanings are relative and contingent and that it is nonsensical to talk about law's role in bringing about social change or justice; they are legitimising the continuation of a status quo that is less than ideal, fair or just. The common response of critical theorists that the function of critique is not to provide alternatives is simply not good enough because critique for the sake of critique is only self-serving for the critics.

Moreover, this is a problematic outcome even for the post-structuralists because contrary to the tenets of post-structuralism, it provides an essentialist answer as it makes the law appear as if it was a pre-discursive object and one with an invariable content and effect of oppression. Even though in a stream of poststructural analysis, it is acknowledged that no law is pre-discursive and the mechanisms of oppression in law are ever changing, the overall import of such analyses still remains that law is oppressive rather than emancipatory. This predominant message of post-structural theories in turn helps avoid focusing on the question of why it is that law cannot be emancipatory.

31 See, for example: Peter Fitzpatrick (ed.), Nationalism, Racism and the Rule of Law, Dartmouth, Brookfield, UK, 1995. 
For instance, this is illustrated well in the analysis of law provided by Stanley Fish. ${ }^{32}$ He sees the judge as free to attribute meaning to the rules of law, as all rules are texts waiting to be interpreted. This is because he insists that any critique of institutional practices depends on invoking an essentialist view that pure knowledge or truth is possible and accessible. It is against this claimed objective standard that the critics argue that institutional practices are problematic. If, however, all knowledge is historically contingent, there is no basis for suggesting that such an ahistorical or universal standard is available as the measure of criticism. It follows in the argument of Fish that dominant perspectives can be explained but not replaced with supposedly neutral or objective views. Importantly, Fish does not concern himself with the issue of how to replace a problematic or dominant perspective with a more desirable, even if contingent perspective, and it is this choice made by Fish and other critical theorists that makes a post-structural analysis unsuitable for connecting law and justice/fairness/non-discrimination.

In conclusion, the relativism of most post-structural analyses of the judicial task is no more convincing than the mainstream claim that it is principled. The arguments, respectively, of Stanley Fish and Ronald Dworkin to me exemplify the shortcomings of both ways of thinking. Thus, all contemporary analyses of law are neglecting a central issue: that any meaning is attributed, created, attached. If so, those involved in such construction must take the responsibility for their choices. That there is a choice in any formulation about the nature of law must become the starting point of any analysis.

\section{Choice and Responsibility}

It is not possible or desirable to go back to a pre-post-structural way of understanding the construction of meaning but we definitely need to move beyond what Foster describes as the postmodernism of reaction to a postmodernism of resistance. ${ }^{33} \mathrm{I}$ understand this to mean that there is a need to extend the post-structural insight about the constructed nature of knowledge but more importantly to link it with the responsibility of those 'doing' the construction. Legal scholars are not only responsible for providing poststructural analyses of law that demonstrate the indeterminacy of meaning, they also must acknowledge their power to attribute meanings.

\footnotetext{
32 For this analysis, I rely on Stanley Fish, 'Anti-Professionalism' (1985) 7 Cardozo Law Review 645. Drucilla Cornell ('Time, Deconstruction, and the Challenge to Legal Positivism: The Call for Judicial Responsibility' (1990) 2 Yale Journal of Law and Humanities 267) challenges this view of Fish's.

33 Hal Foster, 'Postmodernism: A Preface' in Hal Foster (ed.), The Anti-Aesthetic: Essays on Postmodern Culture, Bay Press, Port Townsend, Wash., 1983, p. xii.
} 
There is an undeniable nexus between the institutional location of the thinkers and the authority attributed or accorded to their views. The very fact that not all theorists or analyses are equally influential is cause for asking how certain readings are accepted as authoritative while others are marginalised and ignored. It is not simply a function of the merit of an argument. In some ways, the mainstream legal scholarship that manages to ignore post-structural insights is exhibiting this very nexus between knowledge and power that such scholarship is so good at postulating. More specifically, the post-structural way of thinking requires us to focus on how interpretation is a matter of attaching meaning and always involves making choices. This fact of making choices is effectively obscured in legal scholarship and thus the responsibility for the consequences flowing from those choices does not attach to the decision maker. In the next section, I analyse how responsibility is conceptualised in legal scholarship.

The concept of responsibility is used in various disciplines other than law and it has different meanings than in the discipline of law. ${ }^{34}$ Cane has argued, and I agree, that the concepts of responsibility play an important role in both law and morality, yet philosophers pay little attention to the legal versions of the concept. A careful study of the legal concept of responsibility and legal practices associated with it could, however, be useful to understand responsibility in general. ${ }^{35}$

The ideas of responsibility and legal philosophy have a long connection, but a very cursory survey of legal scholarship on the concept of responsibility shows that most of the writers are engaged in discussing when the law does or should attach responsibility to a legal subject. Primarily these discussions relate to the individual's responsibility in criminal law; responsibility in civil law is discussed to a lesser extent. ${ }^{36}$ What I found missing was any discussion of the responsibility of lawmakers and more particularly of judges for their views. Here I focus only on the lack of scholarly attention to the responsibility of judges. No doubt this is because of the prevalent conventions about the judicial role that these responsibilities are not their own but decisions necessitated by the conventions of legal reasoning that they, as professionals, have to follow. As discussed above, however, there are serious problems with this view and I am helped by Cane, who has argued that the distinction between law and morality also enables us to draw some contrasts between 'moral reasoning' and 'legal reasoning' as techniques for generating normative conclusions about

34 Peter Cane, Responsibility in Law and Morality, Hart Publishing, Oxford, 2002, p. 1.

35 Ibid., pp. 2-3.

36 For a good review of this literature, see: Nicola Lacey, 'Responsibility and Modernity in Criminal Law' (2001) 9(3) Journal of Political Philosophy 249. 
responsibility. ${ }^{37}$ Once it is acknowledged that normative conclusions about legal reasoning follow from the particular concept of legal reasoning, it must be possible to argue for re-conceptualising legal reasoning.

I will discuss this point in the context of the analysis of law and responsibility provided by Veitch. ${ }^{38} \mathrm{He}$ has argued eloquently that judges are not held responsible in their individual capacity because they are acting in the role of the judge. The institutional role of the judge is created precisely so that disputes are decided by reference to the law rather than by reference to the values of the judge as the individual decision maker. Veitch makes this argument as an aspect of his broader argument that law, by design, and not incidentally, dissociates the legal actor from the responsibility for human suffering. The legal norms define what injury is and also define by exclusion that which may be damage but not injury. Thus, suffering caused by the former (damage) is, legally speaking, legitimate. The legal actor's responsibility is transferred to the legal norm and it is the norm that decides when there is an obligation or responsibility. As long as the legal actor is conforming to the legal norm, he or she is guiltless because responsibility stops with fulfilling the legal obligation. ${ }^{39}$ This is an effect of legal categorisation compartmentalising responsibility, so that the legal actor, the judge, is only a conduit of legal authority. ${ }^{40}$ The judge is not personally responsible for the judgment as it is the state of law that is responsible; it is the decision's legal reasoning, and not the reasoning of the actual person, that must do the work of justifying the outcome.

Veitch goes on to argue that even if the judges have discretion, they are merely the mouthpieces of the law and their personal views are, legally speaking, irrelevant. According to Veitch, this is the reason why the judge is not personally responsible because legal responsibility in accordance with the law and the legal role is non-responsibility for the person. ${ }^{41}$ The role usurps the autonomy of the person because when it comes to human beings acting in legal roles, there is only one living person who can act and if the law determines what the right action is the person cannot independently decide otherwise.

At one level, this is a persuasive analysis but I wish to extend it by asking what exactly does it mean to say that the 'law' determines what the right action

\footnotetext{
37 Cane, Responsibility in Law and Morality, p. 3.

38 Scott Veitch, Law and Irresponsibility: On the Legitimation of Human Suffering, Routledge, Oxford, 2007, p. $85 \mathrm{ff}$. His argument is impressively detailed and tightly constructed. It is not possible to do justice to its nuances in this short formulation, but I do believe that it leads to an essentialist view of law.

39 Ibid., p. 87.

40 Earlier in his argument, Veitch has explained that responsibilities are organised as role responsibilitiesthat is, 'action according to a set rule or role is itself blameless'; the role responsibility thus segregates responsibility for the role from the consequences - to act according to a set rule or role is itself blameless (ibid., p. 48).

41 Ibid., p. 88.
} 
is? If this were a straightforward matter, there would be no occasion for the issue to come before the judge. The very existence of the judge is an indication that 'the law' is not unambiguous and an exercise of judgment is required to ascertain what the 'law' is. To hold otherwise, moreover, goes against all the post-structural insights about the nature of meaning and how interpretation is attributing meaning to terms and concepts. It also goes against the obvious fact that 'not only the wording of the positive law makes up the positive law in force at the time; there is also the interpretive practice of the time' ${ }^{42}$ The judge necessarily has to exercise a choice in deciding what 'the law' in any particular instance demands. Once this determination is made, however, the judge is not free to disregard the law, as Veitch persuasively argues. The institutional role to that extent usurps individual autonomy. This last step, however, in no way dispenses with the need to attribute meaning to 'the law' in the first instance. It is by focusing on this prior issue that it becomes clear that judges have to exercise choice in deciding the meaning of the terms used in law.

Conceptually also it needs to be acknowledged that the task of interpretation is a matter of exercising judgment rather than merely performing a mechanical task. Even in the mainstream conception, the judges are choosing an interpretation but they are able to distance themselves from the determinations in the name of their professional responsibility to act according to law rather than acting according to their personal values.

This argument can be easily illustrated in the context of anti-discrimination legislation and the interpretations adopted by judges at various levels of the judicial system. For example, in the case of Purvis, ${ }^{43}$ the judge who cannot understand the disruptive behaviour of the child as an aspect of his disability is no more objective or correct than the judge who sees it otherwise. It is, therefore, not a simple matter of the law determining what the 'right action' is and the judge implementing that. Whether the action of the school is in accordance with the law or not is the very issue that the judge must decide. And to do this the judge must first ascertain what the law demands. The interpretation is

42 Robert Alexy, 'A Defence of Radbruch's Formula' in David Disenhaus (ed.), Recrafting the Rule of Law: The Limits of Legal Order, Hart Publishing, Oxford, 1999, p. 21.

43 Purvis $v$ NSW Department of Education and Training (2003) 217 CLR 92. This case related to Daniel Hoggan, who had an intellectual disability that resulted in him being aggressive and violent at times. The school suspended and eventually excluded him. His foster father, Mr Purvis, brought a case of disability discrimination against the school, invoking the Disability Discrimination Act 1992 (Cth). The dispute went through various levels of the courts and finally the High Court dismissed his application. The majority of judges held that the protection against discrimination on the basis of disability does not extend to functional limitations that may result from the condition. For doctrinal analysis, see: Susan Roberts, 'The Inequality of Treating Unequals Equally: The Future of Direct Discrimination Under the Disability Discrimination Act 1992 (Cth)?' (2005) 45 AIAL Forum 20. 
that of the judge and it is for the judge to choose which interpretative practice to adopt. Whether one describes it as role responsibility, institutional role or anything else, it is ultimately a task that demands an exercise of choice.

Moreover, this exercise of choice is a matter of judgment and I would like to argue that the judges, in deciding whether a practice is discriminatory or not, are as aware of the demands of justice and fairness as the next person. Their seeming inability to name the unfair or unjust practice as 'discrimination' is due not so much to particular understandings of equality and discrimination but to a large extent is a function of being able to distance themselves from 'their' decisions in the name of upholding the law.

If, however, it is argued that the conception of the judicial act in this chapter seems to free the judge of any constraint and therefore has the potential to lead to an unfettered exercise of power, the solution for that problem lies in conceptualising the exercise of authority in a responsible and meaningful manner rather than trying to constrain the judge artificially. A conception of legal reasoning that is more conducive to acknowledging the choices made by judges in interpretation can have a definite advantage. I take support for this view from Alexy, who has argued in a different context that the mere availability of a concept of law - whether positivist or anti-positivist - can have a bearing on the lawmakers' behaviour. Similarly, the availability of a conception of legal reasoning that focuses on the reasonableness or fairness of choices made can create the conditions for judges to adopt interpretations that connect law with justice. ${ }^{44}$

The difference between this conception and that of Dworkin lies in making the judge accountable for their choice of interpretation. The judge would no longer be the ultimate and inscrutable arbiter of the meaning of any rule of law. Instead, they would need to justify their choice in terms of its discriminatory or nondiscriminatory effect. This conception of the judicial role is also in accordance with the post-structural analysis, as, unlike the mainstream theorists, the post-structural theorists explain any judgment as an effect of judicial choice. It extends the post-structural insight, however, in that it demands of the judges that they will exercise their judgment in a responsible manner. Working with this conception of the judicial task, if judges give an interpretation of an anti-discrimination rule that denies or diminishes the human dignity of the complainant, it would be incumbent on them to explain the choice of that interpretation. Importantly, such an explanation would no longer be of the kind that absolves the judge of the responsibility to reach a fair/just/nondiscriminatory solution. 
In another context, Postema has argued persuasively that there is a distinction between the professional responsibility and the responsibility of a layperson, but the professional nevertheless has the responsibility to act in a moral way. ${ }^{45}$ He relies on Aristotle's concept of practical judgment to argue that judgment is neither a matter of simply applying general rules to particular cases nor a matter of mere intuition. Rather it is that in judgment general principles and particularities of a case both come into play. General principles provide the broader framework and a target but not the final outcome. The ultimate decision takes into account the particular circumstances and resolves the conflict of values. Thus, morality is not merely a matter of getting things right but of relating to people in a special and specifically human way. Professionals have to act in specifically moral ways but what can be done is to conceptualise this moral responsibility in a broader sense. This professional responsibility can be linked to understanding the professional role as not a fixed role. A 'recourse role' conception of the professional role allows for the possibility that such a role requires 'the agent not only to act according to what he perceives to be the explicit duties of the role in a narrow sense, but also to carry out those duties in keeping with the functional objectives of the role' ${ }^{46}$

\section{Functional Objectives of the Role of the Judge}

The fact that so many judges cannot see the wrongness of discrimination in the actions of the respondents is not an indication of their lack of moral values. Rather it is a function of a lack of agreement about the functional objectives of the role of judges - that is, whether they are constrained or free to exercise their judgment. The freedom to exercise discretion is not, however, synonymous with unfettered freedom because, if as argued above there is no 'law' pre-existing the determination made by the judge, it seems obvious that in a disputed case the judge has to ascertain the meaning of the law, in the form of a rule or concept. Thus, a legal rule that says that less favourable treatment on the basis of disability is prohibited at the very least requires the judge to decide whether a particular conduct constitutes less favourable treatment. That is, what the law demands is the very issue in dispute and it is only the judge who has the authority to decide. The contemporary judicial practices give the judge an option to focus on the technical aspects rather than the substantive outcomes

45 He makes his argument with regard to lawyers, but I think it is equally applicable to the actions of judges. See Gerald Postema, 'Moral Responsibility in Professional Ethics' (1980) 55 New York University Law Review 63 , esp. at 68.

46 Ibid., 83. 
of the matter. If, however, the interpretative practice demanded a focus on the substantive outcome of the interpretation, it would make for the possibility of judges making more realistic determinations.

In a slightly different context, Judith Butler's argument about gender as 'performative' ${ }^{47}$ needs to be invoked in the context of law as well. 'Law' is not a natural category; it is constructed and, when judges, among others, engage in interpretation of any rule they are attributing meaning to that rule or concept. Similarly, when scholars explain the nature of law, they too are conceptualising rather than describing a pre-existing reality. A theory of judicial task that conceives the judge as personally responsible for their decision would make it inevitable that the judge does not formulate the dispute in technical terms. If the judges could make this understanding of law their starting point it is possible to imagine that discrimination issues would be resolved to achieve genuine non-oppression. For example, the dispute in the case of Purvis $^{48}$ or of Amery, ${ }^{49}$ if decided under this conception of the judicial task, could have had a very different outcome.

In the case of Amery, a group of women claimed that they performed the same tasks as the permanent teachers but were paid less because they were employed as long-term casual teachers. They framed their claim as one of indirect discrimination under the Anti-Discrimination Act 1977 (NSW) (ADA). They argued that the employer made it a condition of work that the teachers had to be employed as permanent staff before they could access the higher pay scales. The long-term casual teachers claimed that they were unable to meet this condition because of the gendered expectations imposed on them as women that they would give priority to family responsibilities.

The majority in the High Court, however, found that the casual employment was not a 'condition of employment' imposed by the employer and therefore the $A D A$ was not relevant. Therefore, the issue of whether the different pay scales were discriminatory did not even arise for judicial consideration. At the same time, however, there is nothing in the judgments of the majority that could be classified as incorrect technically. The most that the commentators can say is that the judges should have defined the requirement of permanent employment as a 'condition' imposed by the employer and thus bring the case under the purview of the $A D A .^{50}$ In the contemporary conventions of legal reasoning, however, judges are able to focus on whether the situation is covered by the

\footnotetext{
47 Judith Butler, Gender Trouble: Feminism and the Subversion of Identity, Routledge, New York, 1999.

48 (2003) 217 CLR 92.

49 NSW v Amery (2006) 226 ALR 196.

50 See, for example, K. Lee Adams, 'Defining Away Discrimination' (2006) 19 Australian Journal of Labour Law 263. Her assessment that the High Court failed to deconstruct the assumptions of normalcy and objectivity and thus equality is fine but it does not provide any reason for hoping that the judges will act differently the next time around. See also Thornton, 'Sex Discrimination, Courts and Corporate Power'.
} 
relevant legislation. Since in their understanding it is not within the purview of the legislation, it becomes irrelevant to consider whether the employment arrangements are unfair for women with family responsibilities. That is, the $A D A$ has a limited scope.

It is of course a truism that the judges can give relief only if the relevant law is applicable. Whether the law is applicable or not itself requires, however, a more nuanced understanding of their responsibility. If the same judges were to operate in a milieu of equality as fairness and judges' responsibility to reach a non-discriminatory outcome, they could not avoid having to explain why it is acceptable for casual teachers - most of whom are women - to be paid less when they are doing the same work as the permanent teachers. Moreover, judges trained to achieve a fair outcome would be able to argue that the choice of permanent or casual employment is not a real choice but an effect of gender hierarchy that the anti-discrimination laws are meant to address.

Similarly, I suggest that if the majority judges in Purvis had the option of distancing themselves from the judgment made, they would indeed be compelled to make a more reasonable or fairer judgment. The majority judges in this instance were able to say that the school was entitled to exclude a boy with intellectual disabilities as the basis of its decision was discrimination on the ground not of disability, but of his disruptive behaviour. The bifurcation between the disability and the behaviour of the person is breathtakingly ingenious but the more important issue here is that the judges were able or were permitted by the conventions of legal reasoning to focus on the technicalities.

Now I am not suggesting that the complainant will always be correct and the respondent wrong, but I am arguing for an acknowledgment that there are at least two interpretations and the judge has to choose between them. Since there is no compulsion to choose one interpretation over another, as exemplified in the different judgments of the majority and the minority, it must be obligatory on the judges to explain their choice in terms of substantive outcomes. If a judge in Purvis holds that the school can exclude the student, they must explain why it is not discrimination. The reasoning in the present judgment that the ground of exclusion is not covered by the legislation is a technical reason, which does not deny that the action of the school will disadvantage the student. Instead it avoids the issue of disadvantage or unfairness of the action altogether. It is perfectly understandable that the school has to manage a difficult situation and might not have the resources to do so. If, however, the problem was identified thus many avenues could be explored to find solutions taking into account the interests of both parties. But if the problem is written out of existence - as done by the majority in the High Court - nothing more remains to be done. The difficulties related to disability are privatised and the state and its institutions absolve themselves of any responsibility by relying on technicalities. 
It is in this sense that Veitch is right that the compartmentalisation of legal tasks absolves the judge of the responsibility for the outcome of a decision. Does this mean that it is futile to expect justice from the law and the judges? If yes, is this not a deterministic analysis that portrays law as inherently incapable of delivering justice? How could it be otherwise?

One way out of this dead end is to acknowledge that the judge has to exercise choice in the pursuit of justice or fairness. It has to be the pursuit of these ideals and not the pretended neutrality that provides the legitimation of judicial authority. It is however, not simply a matter of making these ideals the legislative standard that the judges have to apply. ${ }^{51}$ Rather, it must be the requirement of the judicial role that the judges are the pursuers of justice. Justice according to which definition, one could ask? It is easier to answer this question negatively and say that it is certainly not according to the 'neutrality of the judge' standard. It necessarily means that the judge has to articulate and justify their choice of interpretation as fair or just. The emphasis is on 'justify' and in my opinion this responsibility can be discharged only if we move away from the fiction of constraint on the exercise of discretion. ${ }^{52}$ Such a move will not be a licence for relativism in the sense that a judge is free to be totally arbitrary or idiosyncratic. The constraint in this conception of the judicial task comes from the judge's responsibility for pursuing justice or fairness. It also does not allow judges to distance themselves from the consequence of the decision and thus pins the responsibility of the consequences of the decision on the person making the choice. The disjuncture between role responsibility and personal responsibility is thus avoided but the person occupying the role of the judge cannot leave their morals at home! Undoubtedly, in a morally pluralistic society there would be inevitable disagreements about which morals are worth enforcing through the judiciary. This is an important issue but it is not one resolved by either relying on the fiction of constraint or giving in to the relativism of post-structural views. In the present context, the accountability of the judge for the interpretation chosen is the best guarantee of non-arbitrariness.

\footnotetext{
51 For example, suppose the conventions of legal reasoning demanded that in anti-discrimination actions the outcome should be geared to integrating the complainant in a particular setting (for example, the mainstream school in Purvis). It will still fall on the judge to determine what may be classified as adequate integration. The only certainty that the judge will be sympathetic to the complainant's disadvantage can come from the judge taking personal responsibility for the consequences flowing from their decision.

52 As argued by formalists as well as by natural-law theorists - in particular, those such as Dworkin. See, for example: R. M. Dworkin, 'Is Law a System of Rules' in R. M. Dworkin (ed.), The Philosophy of Law, Oxford University Press, UK, 1977.
} 


\section{Conclusion}

The obvious question of course is how can this view of the judicial task be made the mainstream view? It is not simply a matter of theoretically re-conceptualising the judicial role. Such ideas need to be adopted by the legal professionals and thinkers alike. I have critiqued above the analyses that expect judges to change their ways simply because the scholars 'show' them the shortcomings of their views. The same criticism would apply to the expectation that the theorists will change their conceptions of legal reasoning because of critics' arguments.

Therefore, for this re-conceptualisation to succeed, the transformative potential of legal education needs to be deployed. New ways of theorising the connections between ideas and responsibility for the consequences flowing from those ideas will only ever come from the young legal scholars trained to be independent thinking agents. If combined with a sufficiently broad-based legal education, this conception has the potential for connecting law and justice in a principled as well as practical manner.

Therefore, we need to refocus on the transformative potential of knowledge and especially of education, as it is the site where knowledge is produced and disseminated. I use legal education as my particular focus but the argument is wider in its scope and extendable to education in general. It is necessary to combine the post-structural insights about the constructed nature of knowledge and the responsibility of scholars for their views.

Just as I have argued above about judicial responsibility, so too it can be expected that the theorists are accountable for the consequences flowing from their critiques. For this to happen, it is necessary to create the possibility and the capacities for critical thinking in the students. The idea of critical thinking is paid lip-service to in the burgeoning legal education literature, ${ }^{53}$ but I argue that genuine critical thinking requires an appreciation that ideas are formulated by thinkers who always come from a particular perspective. The insight that objective knowledge is not possible has to be associated with the further acknowledgment that the particular perspective adopted by a thinker needs to be justified. Whether the theorist convinces the readers or not involves them

53 Legal education as a topic has generated extensive scholarship but I will not review it here. My point is, however, illustrated well by the Australian Universities Teaching Committee report that chronicles the extreme diversity of practices in Australian law school curricula. Diversity in itself is not the problem but the fact that there is no systematic attempt at articulating how critical capacities of students can be developed in university training. See Richard Johnstone and Sumitra Vignaendra, Learning Outcomes and Curriculum Development in Law: A Report commissioned by the Australian Universities Teaching Committee (AUTC), Commonwealth of Australia, Canberra, 2003. 
(us) in legitimising ideas. Therefore, the single most important aspect of training critical thinkers is that students (and thus the future professionals) learn to ask how ideas are normalised and legitimised. ${ }^{54}$

The acknowledgment by each one of us must follow that when we accept ideas and theories we are active agents in the process of 'creating' authoritative knowledge. Such critical thinkers who can capture their agency in the legitimation of ideas will of necessity also understand their role in making and unmaking social structures. ${ }^{55}$ Once the individual thinker is thus implicated in making sense of the social structures it should become that much harder for the theorists to propose ideas that leave out of the theory the responsibility of the thinker. That is, if the thinker is not simply describing the surrounding reality but also partly 'constitutes' it then it is logical to expect that the injustices of the contemporary arrangements ought not be allowed to go on unchecked. Otherwise those 'constituting' such arrangements as inevitable are complicit in perpetuating them. If all that the theorists can do is establish the inevitable nature of contemporary societies, it is another way of being determinists. ${ }^{56}$ Critique for the sake of critique can only be self-serving for the scholars. ${ }^{57}$ Therefore, ethical responsibility can and ought to be inculcated as an integral aspect of education as it follows directly from the contemporary theories of knowledge.

In legal education, integrating legal theory in the entire curriculum is one possible way of inculcating critical thinking capacities of students. ${ }^{58}$ To achieve this aim, however, it is crucial that students are engaged in analysing a broad spectrum of theoretical ideas. ${ }^{59}$ That is, unless the students of law are trained to critique every idea and recognise their own agency in legitimising particular ideas, they are simply going to reproduce the authoritative knowledge that they are taught. It matters very little that what counts as authoritative could now be in the post-structural genre. Generating the capacity for the self-reflexivity

54 The enormity of this task is undeniable and the institutional obstructions are well analysed by Margaret Thornton 'Gothic Horror in the Legal Academy' (2005) 14(2) Social and Legal Studies 267.

55 I take this idea from Henry Giroux, 'Pedagogy of the Depressed: Beyond the New Politics of Cynicism' (2001) 28(3) College Literature 1, 14-15.

56 Cornel West, 'On Fox and Lears's The Culture of Consumption', Prophetic Fragments, Africa World Press, Lawrenceville, NJ, 1988.

57 Joel Pfister, Critique for What: Cultural Studies, American Studies, Left Studies, Paradigm Publishers, London, 2006.

58 I have developed this argument in greater detail in Archana Parashar and Vijaya Nagarajan, 'An Empowering Experience: Repositioning Critical Thinking Skills in the Law Curriculum' (2006) 10 Southern Cross Law Review 219. See also: Amita Dhanda, 'The Power of One: the Law Teacher in the Academy' in Amita Dhanda and Archana Parashar (eds), Decolonisation of Legal Knowledge, Routledge, Delhi, 2009.

59 A further difficulty, however, is that in legal education the inclusion of any theory is already a contentious issue and to argue for the inclusion of diverse streams is that much more difficult. See: Ian Duncanson, 'Legal Education and the Possibility of Critique: An Australian Perspective' (1993) 8 Canadian Journal of Law and Society p. 59. For an example of the debates, see also the articles in the special issue of Sydney Law Review (vol. 26 [2004]). 
of thinkers in accepting or rejecting ideas is the logical basis of connecting responsibility with agency. These students are the legal thinkers of tomorrow and if equipped to think for themselves they will be the authors of a responsible jurisprudence of equality.

\section{Bibliography}

\section{Books and articles}

Adams, K. Lee, 'Defining Away Discrimination' (2006) 19 Australian Journal of Labour Laws 263.

Alexy, Robert, 'A Defence of Radbruch's Formula' in David Disenhaus (ed.), Recrafting the Rule of Law: The Limits of Legal Order, Hart Publishing, Oxford, 1999.

Butler, Judith, Gender Trouble: Feminism and the Subversion of Identity, Routledge, New York, 1999.

Cane, Peter, Responsibility in Law and Morality, Hart Publishing, Oxford, 2002.

Cappelletti, Maur, 'Who Watches the Watchmen? A Comparative Study of Judicial Responsibility' (1983) 31 American Journal of Comparative Law 1.

Chaffey, Claire, 'Human rights proposal still afloat', Lawyers Weekly, 22 February 2010, LexisNexis, <http:/www.lawyersweekly.com.au/blogs/top_stories/ archive/2010/02/22/human-rights-proposal-still-afloat.aspx $>$

Colker, Ruth, 'Anti-Subordination Above All: Sex, Race and Equality Protection' (1986) 61 New York University Law Review 1003.

Cornell, Drucilla, 'Time, Deconstruction, and the Challenge to Legal Positivism: The Call for Judicial Responsibility' (1990) 2 Yale Journal of Law and Humanities 267.

Davis, Martha, 'The Equal Rights Amendment: Then and Now' (2008) 17(3) Columbia Journal of Gender and Law 419.

Dean, Jodi (ed.), Feminism and the New Democracy: Resisting the Political, Sage, London, 1997.

Dhanda, Amita, 'The Power of One: the Law Teacher in the Academy' in Amita Dhanda and Archana Parashar (eds), Decolonisation of Legal Knowledge, Routledge, Delhi, 2009. 
Sex Discrimination in Uncertain Times

Duncanson, Ian, 'Legal Education and the Possibility of Critique: An Australian Perspective' (1993) 8 Canadian Journal of Law and Society 59.

Dworkin, Ronald, 'Is Law a System of Rules' in R. M. Dworkin (ed.), The Philosophy of Law, Oxford University Press, UK, 1977.

Dworkin, Ronald, Law's Empire, Harvard University Press, Cambridge, Mass., 1986.

Fish, Stanley, 'Anti-Professionalism' (1985) 7 Cardozo Law Review 645.

Fitzpatrick, Peter (ed.), Nationalism, Racism and the Rule of Law, Dartmouth, Brookfield, UK, 1995.

Foster, Hal (ed.), The Anti-Aesthetic: Essays on Postmodern Culture, Bay Press, Port Townsend, Wash., 1983.

Franke, Katherine M., 'The Central Mistake of Sex Discrimination Law: The Disaggregation of Sex From Gender' (1995-96) 144 University of Pennsylvania Law Review 1.

Fraser, Nancy, Justice Interruptus: Critical Reflections on the 'Postsocialist' Condition, Routledge, New York, 1997.

Gaze, Beth, 'Context and Interpretation in Anti-Discrimination Laws' (2002) 26(2) Melbourne University Law Review 325.

Gaze, Beth, 'The Sex Discrimination Act After Twenty Years: Achievements, Disillusionments and Alternatives' (2004) 27(3) UNSW Law Journal 914.

Gilbert and Tobin Centre of Public Law, History of Charters of Human Rights in Australia, University of New South Wales, Sydney, <http://www.gtcentre. unsw.edu.au/Resources/cohr/historyChartersofHumanRights.asp>

Giroux, Henry, 'Pedagogy of the Depressed: Beyond the New Politics of Cynicism' (2001) 28(3) College Literature 1.

Herman, Didi, 'Beyond the Rights Debate' (1993) 2 Social and Legal Studies 25.

Higgins, Tracy E. and Rosenbury, Laura A., 'Agency, Equality and AntiDiscrimination Law' (1999-2000) 85 Cornell Law Review 1194.

Hunter, Rosemary (ed.), Rethinking Equality Projects in Law: Feminist Challenges, Hart Publishing, Oxford and Portland, Ore., 2008.

Hunyor, Jonathon, 'Skin-Deep: Proof and Inferences of Racial Discrimination in Employment' (2003) 25 Sydney Law Review 535. 
Lacey, Nicola, 'Responsibility and Modernity in Criminal Law' (2001) 9(3) Journal of Political Philosophy 249.

Lacey, Nicola, 'Feminist Legal Theory and the Rights of Women' in Karen Knop (ed.), Gender and Human Rights, Academy of European Law, Oxford University Press, UK, 2004.

McCrudden, Christopher (ed.), Anti-Discrimination Law, Dartmouth/Ashgate, Aldershot, UK, 2004.

Mansbridge, Jane J., Why We Lost the ERA, University of Chicago Press, Ill., 1986.

Moody-Adams, Michele, 'Reclaiming the Ideal of Equality' in Barbara S. Andrew, Jean Keller and Lisa H. Schwartzman (eds), Feminist Interventions in Ethics and Politics, Rowman and Littlefield Publishers, Oxford, 2005.

Parashar, Archana, 'Responsibility for Legal Knowledge' in Amita Dhanda and Archana Parashar (eds), Decolonisation of Legal Knowledge, Routledge, Delhi, 2009.

Parashar, Archana and Nagarajan, Vijaya, 'An Empowering Experience: Repositioning Critical Thinking Skills in the Law Curriculum' (2006) 10 Southern Cross Law Review 219.

Pfister, Joel, Critique for What: Cultural Studies, American Studies, Left Studies, Paradigm Publishers, London, 2006.

Postema, Gerald, 'Moral Responsibility in Professional Ethics' (1980) 55 New York University Law Review 63.

Roberts, Susan, 'The Inequality of Treating Unequals Equally: The Future of Direct Discrimination Under the Disability Discrimination Act 1992 (Cth)?' (2005) 45 AIAL Forum 20.

Rosenfeld, Michel, 'Deconstruction and Legal Interpretation: Conflict, Indeterminacy and the Temptations of the New Legal Formalism' in Drucilla Cornell, Michel Rosenfeld and David Gray Carlson (eds), Deconstruction and the Possibility of Justice, Routledge, New York, 1992, p. 152.

Sadurski, Wojciech, 'Equality Before the Law: A conceptual Analysis' (1986) 60 Australian Law Journal 131.

Sadurski, Wojciech, Equality and Legitimacy, Oxford University Press, New York, 2008.

Sen, Amartya, Inequality Reexamined, Oxford University Press, UK, 1992. 
Smith, Belinda, 'It's About Time for a New Regulatory Approach to Equality' (2008) 36 Federal Law Review 117.

Smith, Belinda and Riley, Joellen, 'Family Friendly Work Practices and the Law' (2004) 26 Sydney Law Review 395.

Squires, Judith, The New Politics of Gender Equality, Palgrave Macmillan, Basingstoke, UK, 2007.

Sullivan, Barbara, 'Sex Equality and the Australian Body Politic' in S. Watson (ed.), Playing the State, Allen \& Unwin, Sydney, 1990.

Thornton, Margaret, The Liberal Promise: Anti-Discrimination Legislation in Australia, Oxford University Press, Melbourne, 1990.

Thornton, Margaret, 'Gothic Horror in the Legal Academy' (2005) 14(2) Social and Legal Studies 267.

Thornton, Margaret, 'Sex Discrimination, Courts and Corporate Power' (2008) 36 Federal Law Review, 31.

Veitch, Scott, Law and Irresponsibility: On the Legitimation of Human Suffering, Routledge, Oxford, 2007.

West, Cornel, 'On Fox and Lears's The Culture of Consumption', Prophetic Fragments, Africa World Press, Lawrenceville, NJ, 1988.

Wright, Shelley, 'Human Rights and Women's Rights' in K. E. Mahoney and P. Mahoney (eds), Human Rights in the Twenty-First Century, M. Nijhoff, Dordrecht, Boston, 1993.

\section{Legislation}

Anti-Discrimination Act 1977 (NSW)

Disability Discrimination Act 1992 (Cth)

Sex Discrimination Act 1984 (Cth)

\section{Cases}

NSW v Amery (2006) 226 ALR 196

Purvis v NSW Department of Education and Training (2003) 217 CLR 92 


\section{Reports and miscellaneous primary sources}

Australian Law Reform Commission, Equality Before the Law: Women's Equality, Report No. 69, Australian Law Reform Commission, Sydney, 1994, Part II.

Johnstone, Richard and Vignaendra, Sumitra, Learning Outcomes and Curriculum Development in Law: A Report commissioned by the Australian Universities Teaching Committee (AUTC), Commonwealth of Australia, Canberra, 2003.

Senate Standing Committee on Legal and Constitutional Affairs, Report on the Effectiveness of the Commonwealth Sex Discrimination Act 1984 in Eliminating Discrimination and Promoting Gender Equality, Parliament of Australia, Canberra, 2008, <http://www.aph.gov.au/Senate/committee/legcon_ctte/ sex_discrim/report/index.htm $>$ 